\title{
STRATEGI PEMBELAJARAN MELALUI PENDEKATAN KONTEKSTUAL DENGAN COOPERATIVE LEARNING UNTUK MENINGKATKAN HASIL BELAJAR GELOMBANG SISWA KELAS XII MAN 1 BANDAR LAMPUNG
}

\author{
Ahmad Gumrowi \\ MAN 1 Bandar Lampung, e-mail: gumrowi@gmail.com \\ Diterima: 2 September 2016. Disetujui: 12 Oktober 2016. Dipublikasikan: Oktober 2016
}

\begin{abstract}
This classroom action research aims to improve student learning outcomes on the lesson of waves at MAN 1 Bandar Lampung using contextual approach with cooperative learning strategies. The objective of this study is the result of students' learning on the lesson of waves which used the contextual approach with cooperative learning strategies. The research was conducted in three cycles. The results of analysis show that contextual approach with cooperative learning strategies can improve students' learning outcomes on the lesson of the waves. The average student learning outcomes in the first cycle is 67,90 and the second cycle is 75,70; it means it gets increased by 11,49\%. While the average learning results in the third cycle is 79.77, it gets increased by $5,37 \%$.
\end{abstract}

\begin{abstract}
Abstrak: Penelitian tindakan kelas ini bertujuan untuk meningkatkan hasil belajar Fisika materi gelombang, siswa MAN 1 Bandar Lampung dengan menggunakan strategi pembelajaran melalui pendekatan kontekstual dengan cooperative learning. Variabel terikat penelitian ini adalah hasil belajar siswa pada pokok bahasan gelombang dengan strategi pembelajaran melalui pendekatan kontekstual dengan cooperative learning. Penelitian dilaksanakan selama tiga siklus, dari hasil analisis diperoleh bahwa strategi pembelajaran melalui pendekatan kontekstual dengan cooperative learning dapat meningkatkan hasil belajar siswa pokok bahasan gelombang. Rata-rata hasil belajar siswa pada siklus I sebesar 67,90 dan siklus II menjadi 75,70 dengan demkian ada peningkatan $11,49 \%$. Sedangkan rata-rata hasil belajar pada siklus III 79,77 atau meningkat $5,37 \%$.
\end{abstract}

(C) 2016 Pendidikan Fisika, FTK IAIN Raden Intan Lampung

Kata Kunci: cooperatif learning, gelombang, pendekatan kontekstual

\section{PENDAHULUAN}

Pendidikan yang bermutu, akan menghasilkan sumber daya manusia yang berkualitas dan berdaya saing tinggi. Salah satu persoalan yang belakangan ini dihadapi bangsa Indonesia adalah rendahnya kualitas pendidikan, baik pada tingkat dasar maupun tingkat menengah.

Dalam skala mikro rendahnya kualitas pendidikan dapat dilihat dari rendahnya perolehan nilai ujian siswa yang merupakan indikator pencapaian hasil belajar. Salah satu mata pelajaran yang termasuk kategori rendah adalah fisika, Tinggi rendahnya hasil belajar fisika siswa disebabkan oleh beberapa faktor, baik faktor yang berasal dari dalam maupun faktor yang berasal dari luar diri siswa

Rendahnya hasil belajar ini diduga karena pendekatan pembelajaran yang digunakan oleh guru pada proses pembelajaran sangat kurang tepat dan pengelolaan kegiatan pembelajaran yang masih belum dapat membangkitkan motivasi belajar siswa secara optimal. Pendekatan pembelajaran yang dilakukan oleh guru harus diciptakan secara teratur untuk mewujudkan keberhasilan dari proses kegiatan belajar mengajar di kelas.

Pemilihan model pembelajaran sangat menentukan akan keberhasilan dan tingkat penguasaan siswa terhadap suatu pelajaran. Model pembelajaran mestinya 
dapat menjembatani antara pengalaman sehari-hari dengan materi pelajaran. Dengan adanya kaitan tersebut maka pengetahuan kognitif dapat dibangun dengan pengalaman yang pernah dialami. Dengan modal pengalaman sehari-hari yang dialami dan dikaitkan dengan pokok bahasan yang dipelajari, sangat memungkinkan penguasaan siswa akan jauh lebih baik.

Salah satu strategi atau model pembelajaran yang mengaitkan antara pengalaman sehari-hari dengan materi pelajaran adalah Contextual Teaching and Learning (CTL). Menurut Komalasari (2010: 7) mendefinisikan pembelajaran kontekstual adalah pembelajaran yang mengaitkan materi yang dipelajari dengan kehidupan nyata siswa sehari-hari, baik dalam lingkungan, keluarga, sekolah, masyarakat maupun warga negara dengan tujuan untuk menemukan makna materi tersebut bagi kehidupan.

Hal senada disampaikan oleh Suprijono (2009: 79) CTL merupakan konsep yang membantu guru mengaitkan antara materi yang diajarkan dengan situasi dunia nyata dan mendorong peserta didik membuat hubungan antara pengetahuan yang dimiliki dengan penerapan dalam kehidupan mereka sebagai anggota keluarga dan masyarakat. Pengetahuan dan keterampilan siswa diperolah dari usaha siswa mengonstruksikan sendiri pengetahuan dan keterampilan baru ketika ia belajar Nurhadi (dalam Muslich, 2011: 41)

Sedangkan Sanjaya (2006: 109) CTL adalah pembelajaran yang menekankan kepada proses keterlibatan siswa secara penuh untuk dapat menemukan materi yang dipelajari dan menghubungkannya dengan situasi kehidupan nyata sehingga mendorong siswa untuk dapat menerapkannya dalam kehidupan mereka.

Dengan demikian dapat dikatakan bahwa CTL merupakan pembelajaran yang mengaitkan antara materi dengan situasi dunia nyata yang saling terhubung dan terjadi di sekitar siswa sehingga siswa lebih mudah dalam memahami materi yang dipelajari dan mengambil manfaatnya serta dapat menerapkannya dalam kehidupan.

Model pembelajaran Contextual Teaching and Learning (CTL) memiliki karakter tertentu. Menurut Muslich (2011:

42) karakter CTL sebagai berikut :

1. Pembelajaran dilaksanakan dalam konteks autentik, yaitu pembelajaran yang diarahkan pada ketercapaian keterampilan dalam konteks kehidupan nyata atau pembelajaran yang dilaksanakan dalam lingkungan yang alamiah (learning in real life setting).

2. Pembelajaran memberikan kesempatan kepada siswa untuk mengerjakan tugas-tugas yang bermakna (meaningful learning).

3. Pembelajaran dilaksanakan dengan memberikan pengalaman bermakna kepada siswa (learning by doing).

4. Pembelajaran dilaksanakan melalui kerja kelompok, berdiskusi, saling mengoreksi antar teman (learning in a group).

5. Pembelajaran memberikan kesempatan untuk menciptakan rasa kebersamaan, bekerja sama, saling memahami antar satu dengan yang lain secara mendalam (learning to know each other deeply).

6. Pembelajaran dilaksanakan secara aktif,kreatif, produktif, dan mementingkan kerja sama (learning to ask, to inquri, to work together).

7. Pembelajaran dilaksanakan dalam situasi yang menyenangkan (learning as an enjoy activity).

Strategi pembelajaran Contextual Teaching and Learning (CTL) akan sejalan dengan cooperatif learning. Menurut Slavin (1997:284) "Pembelajaran kooperatif adalah; Pembelajaran di mana siswa belajar dalam suatu kelompok kecil, saling membantu dalam 
memahami materi pelajaran, menyelesaikan tugas atau kegiatan lain agar semua siswa dalam kelompok mencapai hasil belajar yang tinggi."

Salah satu model pembelajaran kooperatif adalah Team Assisted Individualization (TAI). Pembelajaran tipe ini merupakan pembelajaran yang menggabungkan belajar kooperatif dengan individu. Dalam menyelesaikan tugas kelompok, masing-masing anggota kelompok bertanggung jawab terhadap keberhasilan kelompoknya karena keberhasilan kelompok ditentukan oleh masing-masing anggota kelompok, dalam hal ini setiap anggota kelompok harus bekerja sama dan saling membantu untuk saling memahami materi pelajaran. Pelajaran belum dapat dilanjutkan jika salah satu anggota belum menguasai pelajaran. (Slavin, 1995:7)

Tipe pembelajaran kooperatif TAI (Team Assisted Individualization). kelompok kecil yang terdiri dan 5 sampai 6 orang dengan kemampuan yang heterogen. Siswa mengerjakan tugas dalam kelompok yang heterogen. Dalam menyelesaikan tugas kelompok, masingmasing anggota kelompok bertanggung jawab terhadap keberhasilan kelompoknya. Karena keberhasilan kelompok ditentukan oleh masing-masing anggota kelompok. Setiap anggota kelompok harus bekerja sama dan saling membantu untuk saling memahami pelajaran. Pelajaran belum dapat dilanjutkan jika ada salah satu anggota kelompok belum menguasai materi pelajaran.

Pendapat Slavin (1995), ada beberapa hal yang perlu diperhatikan dalam pembelajaran kooperatif tipe TAI, yaitu

1. Kelompok kecil dibentuk dan siswa dengan kemampuan yang heterogen.

2. Setiap siswa bekerja dalam pembelajaran masing-masing unit.
3. Kelompok menggunakan lembar jawaban untuk memeriksa pekerjaan tiap anggota kelompok, mereka bertanggung jawab untuk meyakinkan bahwa semua anggota kelompok telah siap untuk melaksanakan tes pada akhir tiap unit.

4. Diskusi dan tutor teman sebaya pada tiap anggota kelompok, siswa diharuskan bertanya kepada asisten kelompok terlebih dahulu sebelum bertanya kepada guru.

5. Nilai kelompok diambil dan ratarata nilai tes tiap unit yang diperoleh tiap anggota kelompok. Kelompok yang nilainya mencapai kriteria objektif menerima penghargaan. Dalam hal ini guru berperan sebagai sumber belajar.

Rumusan masalah pada penelitian ini adalah Apakah strategi pembelajaran Melalui Pendekatan Kontekstual dengan Cooperative Learning dapat meningkatkan hasil belajar Gelombang siswa kelas XII.A.1 Semester 1 MAN 1 Bandar Lampung?

Pada penelitian tindakan kelas ini peneliti mencoba menerapkan strategi pembelajaran melalui pendekatan Kontekstual model cooperative learning. Dengan strategi ini siswa diharapkan akan tertarik dan termotivasi sehingga siswa aktif mengikuti kegiatan belajar mengajar, dengan demikian hasil belajar fisika pada pokok bahasan gelombang siswa akan meningkat.

Penelitian ini sejalan dengan apa yang dilakukan oleh Muhamad Fajar Buana (2012) tentang Penerapan CTL Dengan Kooperatif NHT Pada Mata Pelajaran Biologi Untuk Meningkatkan Motivasi Belajar Siswa SMA Muhammadiyah 1 Malang bahwa Penerapan CTL dengan Kooperatif $N H T$ dapat meningkatkan motivasi belajar 
biologi siswa kelas XI IPA SMA Muhammadiyah 1 Malang

Penelitian serupa juga dilakukan oleh Setiawan, Didik (2012) tentang Upaya Meningkatkan Hasil Belajar IPA Tentang Ciri-Ciri Khusus Makhluk Hidup Dengan Pendekatan CTL (Contextual Teaching And Learning) Bagi Siswa Kelas VI SDN Teges Purworejo.

Demikian juga penelitian yang dilakukan oleh Rani Nuraini (2013) tentang Penerapan Contextual Teaching And Learning (CTL) Untuk Meningkatkan Hasil Belajar Siswa Pada Standar Kompetensi Memupuk, bahwa dilihat dari test hasil belajar yang meningkat dari tiap siklus, Penerapan Contextual Teaching and Learning (CTL) dapat meningkatkan Hasil belajar siswa pada standar kompetensi memupuk di SMK-PP N 1 Cianjur kelas XB Tahun Ajaran 2012-2013

Adapun Tujuan penelitian tindakan kelas ini adalah:

1. Untuk meningkatkan hasil belajar gelombang siswa kelas XII.A.1 semester 1 MAN 1 Bandar Lampung dengan menggunakan strategi pembelajaran Melalui Pendekatan Kontekstual Model Cooperative Learning.

2. Mengetahui seberapa besar kenaikan hasil belajar Gelombang siswa kelas XII.A.1 MAN 1 Bandar Lampung dengan menggunakan strategi pembelajaran Melalui Pendekatan Kontekstual Model Cooperative Learning

Manfaat dari penelitian ini sebagai informasi bagi guru mengenai alternatif strategi pembelajaran yang dapat mengaitkan antara kehidupan sehari-hari dengan kegiatan pembelajaran di kelas dan dapat membimbing siswa untuk Lebih aktif dalam proses pembelajaran.

\section{METODE PENELITIAN}

Penelitian tindakan kelas ini dilaksanakan di MAN 1 Bandar Lampung yang berlokasi di Jl. Letkol. H. Endro Suratmin, Kel. Korpri Jaya Kec. Sukarame Bandar Lampung.

Penelitian tindakan kelas dilaksanakan 3 siklus, berlangsung selama satu bulan. Rincian Prosedur Penelitian pada tiap-tiap siklus terdiri dari empat tahapan, yaitu: 1) Perencanaan (planning); 2) Pelaksanaan tindakan (acting); 3) Pengamatan (observasing); 4) Refleksi berdasarkan hasil pengamatan (reflecting). Keempat tahap merupakan sebuah siklus, yaitu satu putaran kegiatan beruntun yang kembali ke langkah semula. (Suharsimi Arikunto, 2007:16).

Tahap-tahap dalam setiap siklus pada penelitian tindakan ini terdiri dari 4 tahap yakni tahap perencanaan, pelaksanaan. pengamatan dan refleksi.

\section{Perencanaan}

a. Membuat perangkat pembelajaran RPP .

b. Menyusun skenario pembelajaran sesuai dengan materi.

c. Menyiapkan materi pembelajaran yang akan dipelajari siswa

d. Mempersiapkan lembar observasi atau catatan lapangan.

\section{Pelaksanaan}

\section{a. Kegiatan Awal}

1) Guru terlebih dahulu menjelaskan strategi pembelajaran.

2) Guru menyampaikan tujuan pembelajaran dan mengenalkan kepada siswa hal-hal dalam kehidupan sehari-hari yang berkaitan dengan materi yang diajarkan.

3) Membagi siswa ke dalam kelompok-kelompok, setiap kelompok terdiri dan 5 orang siswa.

\section{c. Kegiatan Inti}


1) Pemberian materi yang diberikan oleh guru kurang lebih 10 sampai 15 menit.

2) Setelah penyajian materi, siswa berkelompok sesuai dengan kelompoknya. Masing-masing anggota kelompok mengerjakan lembar kegiatan dan berdiskusi dengan teman kelompoknya untuk saling memeriksa hasil dari pekerjaannya dalam latihan yang ada pada lembar kegiatan tersebut.

3) Siswa berdiskusi dan kerja kelompok serta mengerjakan latihan yang diberikan oleh peneliti.

4) Guru mengamati diskusi dan kerja kelompok dengan memberikan bimbingan jika perlukan.

5) Guru /peneliti memberikan kesempatan kepada masingmasing kelompok atau siswa untuk bertanya.

6) Guru meminta kepada beberapa perwakilan kelompok untuk mempresentasikan melalui simulasi hasil belajar kelompok.

\section{d. Penutup}

1) Guru membimbing siswa menyimpulkan hasil kerja kelompok

2) Pada setiap siklus siswa diberikan tes secara individu ( ulangan ) untuk mengetahui sampai sejauh mana hasil belajar siswa.

3) Guru/peneliti memberikan penghargaan kepada kelompok dengan hasil presentasi yang terbaik.

4) Apabila terdapat siswa yang memperoleh hasil ulangan dengan nilai $<77$ sebagai kriteria ketuntasan minimal yang diharapkan maka hal ini berarti perlu dilaksanakan perbaikan pada siklus berikutnya.

\section{Pengamatan atau Observasi}

Pengamatan proses pembelajaran peneliti dibantu oleh teman sejawat yang juga mengajar kelas XII Hasil pengamatan ini dituangkan dalam catatan lapangan (lembar observasi) yang telah dipersiapkan.

\section{Refleksi}

Pada tahap refleksi peneliti dan teman sejawat mendiskusikan temuantemuan yang diperoleh pada kegiatan yang telah dilaksanakan baik keberhasilan atau kegagalannya, yang selanjutnya akan menjadi landasan siklus berikutnya.

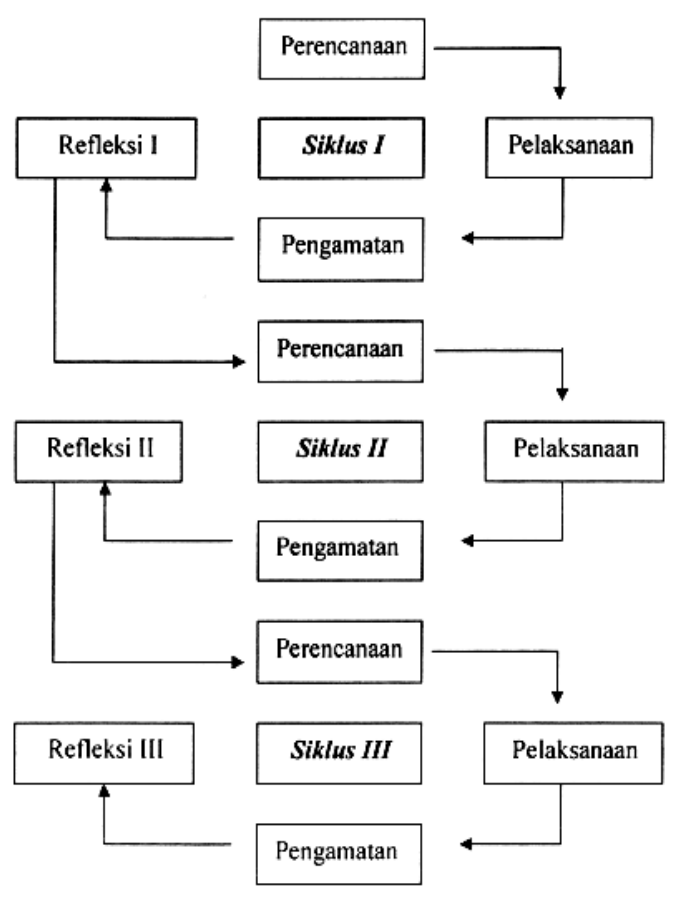

Gambar. 1 Bagan Tahapan Siklus Penelitian Tindakan Kelas

Prosedur di atas akan berulang untuk siklus II dan siklus III.

Hasil analisis dan refleksi digunakan sebagai bahan perbaikan tindakan pada siklus berikutnya. Analisis data hasil belajar diambil rata-rata nilai tes yang diberikan setelah mengikuti proses kegiatan pembelajaran menggunakan persamaan

$$
\bar{X}=\frac{\Sigma N S}{N}
$$


Keterangan

$\bar{X} \quad$ : Nilai rata-rata tes

$\Sigma N S \quad$ : Jumlah nilai seluruh siswa

$\mathrm{N}$ : Jumlah siswa

Untuk mengetahui keberhasilannya, hasil analisis dibandingkan dengan indikator keberhasilan. Indikator keberhasilan dapat dilihat dari peningkatan hasil belajar siswa, jika jumlah siswa yang aktif dan nilai rata-ratanya meningkat dari siklus I sampai dengan siklus III, maka proses pembelajaran dikatakan berhasil. Indikator keberhasilan sebagai berikut:

Siswa dapat menyelesaikan masalah tentang Gelombang. Siswa paham tentang materi yang disampaikan dengan pencapaian $75 \%$ siswa dapat tuntas pada kompetensi dasar yang diberikan. Kategori tentang keberhasilan siswa dengan nilai hasil tes $\geq 77$ sesuai dengan KKM.

\section{HASIL DAN PEMBAHASAN}

Hasil tes yang dilakukan pada pertemuan kedua tiap-tiap siklus diperoleh data hasil belajar. Data hasil belajar pada siklus I disajikan pada tabel

Tabel 1. Data hasil belajar pada siklus I

\begin{tabular}{|c|c|c|c|c|}
\hline \multirow{2}{*}{ Kegiatan } & \multicolumn{2}{|c|}{$\begin{array}{c}\text { Ketuntasan } \\
\text { Klasikal (\%) }\end{array}$} & \multirow{2}{*}{$\begin{array}{c}\text { Rerata } \\
\text { Hasil } \\
\text { Belajar }\end{array}$} & \multirow{2}{*}{$\begin{array}{c}\text { Kenaikan } \\
\text { Ketuntas } \\
\text { an }(\%)\end{array}$} \\
\hline & $\begin{array}{c}\text { Jml } \\
\text { Siswa }\end{array}$ & $\%$ & & \\
\hline $\begin{array}{c}\text { Pra } \\
\text { Siklus }\end{array}$ & 7 & 23.33 & 62.80 & - \\
\hline Siklus I & 12 & 40.00 & 67.90 & 71.43 \\
\hline
\end{tabular}

Berdasarkan data pada tabel 1 menunjukkan bahwa pada pra penelitian siswa yang memperoleh nilai $\geq 77$ (tuntas) sebanyak 7 siswa atau $23,33 \%$ sedangkan pada siklus I siswa yang tuntas 12 siswa atau sekitar $40 \%$ dari jumlah siswa. Jika dibandingkan maka mengalami peningkatan $71,43 \%$. Sedangkan rata-rata hasil belajar dari 62,8 menjadi 67,9 atau meningkat $8,12 \%$. Kenaikan ini sangat luar biasa namun demikian persentase ketuntasan belum memenuhi harapan peneliti

Dari analisis pada siklus I dan masukan dari teman sejawat sebagai mitra sebenarnya sudah banyak tindakan positif yang telah dilakukan oleh peneliti untuk memotivasi siswa. Menurutnya ada beberapa tindakan yang harus diperbaiki pada siklus berikutnya, antara lain

1. Peneliti hendaknya menjelaskan lebih rinci tujuan pembelajaran yang akan dilakukan kepada siswa, sehingga siswa akan lebih termotivasi.

2. Peneliti menjelaskan kembali kepada siswa tentang strategi pembelajaran dan prosedurnya. Sehingga semua siswa akan terlibat kegiatan pembelajaran.

Hasil diskusi dengan teman sejawat dan refleksi siklus I maka dilakukan siklus II, data hasil belajar siklus II seperti pada tabel .2

Tabel 2. Data hasil belajar pada siklus II

\begin{tabular}{ccccc}
\hline Kegiatan & $\begin{array}{c}\text { Ketuntasan } \\
\text { Klasikal (\%) }\end{array}$ & $\begin{array}{c}\text { Rerata } \\
\text { Hasil } \\
\text { Belajar }\end{array}$ & $\begin{array}{c}\text { Kenaikan } \\
\text { Ketuntas } \\
\text { an (\%) }\end{array}$ \\
\cline { 2 - 3 } $\begin{array}{c}\text { Jml } \\
\text { Siswa }\end{array}$ & $\%$ & & \\
\hline Siklus I & 12 & 40.00 & 67.90 & 71.43 \\
\hline $\begin{array}{c}\text { Siklus } \\
\text { II }\end{array}$ & 22 & 73.33 & 75.70 & 83.33 \\
\hline
\end{tabular}

Berdasarkan tabel 2, terlihat adanya peningkatan hasil belajar siswa. Berdasarkan catatan lapangan peningkatan ini disebabkan aktivitas siswa baik secara kelompok maupun individu mengalami peningkatan yang signifikan. Hal ini tidak terlepas dari pengelolaan pembelajaran yang semakin baik.

Pada siklus II siswa yang tuntas atau memperoleh nilai $\geq 77$ sebanyak 22 siswa atau 73,33\% dari jumlah siswa. Jika dibandingkan dengan siklus I dari $40 \%$ menjadi $73,33 \%$ mengalami peningkatan $83,33 \%$. Rata-rata hasil belajar siswa pada 
siklus II 75,70, kalau dibandingkan dengan siklus I dari 67,90 menjadi 75,70 berarti mengalami peningkatan sebesar $11,49 \%$. Meskipun hasil belajar mengalami peningkatan yang sangat tajam pada siklus II namun indikator keberhasilan siswa sebesar $75 \%$ dari jumlah siswa belum terpenuhi sehingga perlu refleksi untuk siklus berikutnya.

Hasil diskusi dan refleksi siklus II maka dilakukan siklus III, data hasil belajar siklus III seperti pada tabel.3

Tabel 3. Data hasil belajar pada siklus III

\begin{tabular}{lcccc}
\hline Kegiatan & \multicolumn{2}{c}{$\begin{array}{c}\text { Ketuntasan } \\
\text { Klasikal (\%) }\end{array}$} & $\begin{array}{c}\text { Rerata } \\
\text { Hasil } \\
\text { Belajar }\end{array}$ & $\begin{array}{c}\text { Kenaikan } \\
\text { Ketuntas } \\
\text { an (\%) }\end{array}$ \\
\cline { 2 - 4 } & $\begin{array}{c}\text { Jml } \\
\text { Siswa }\end{array}$ & $\%$ & & \\
\hline Siklus II & 22 & 73.33 & 75.70 & 83.33 \\
\hline Siklus III & 26 & 86.67 & 79.77 & 18.18 \\
\hline
\end{tabular}

Berdasarkan catatan lapangan dan diskusi dengan teman sejawat maka dilakukan siklus III Tahapan-tahapan pada siklus ini juga sama, namun pada akhir siklus III jika hasil tes sesuai dengan indikator yang diharapkan maka penelitian ini dihentikan.

Dari tabel 3, pada siklus III siswa yang memperoleh nilai $\geq 77$ sebanyak 26 siswa atau $86,67 \%$. Jika dibandingkan dengan siklus II dari $73,33 \%$ menjadi $86,67 \%$ meningkat $18,18 \%$. Sedangkan nilai rata-rata hasil belajar pada siklus II sebesar 79,77. Jika dibandingkan dengan siklus II dari 75,70 menjadi 79,77 berarti meningkat $5,37 \%$.

Dari penjelasan di atas jelaslah bahwa strategi pembelajaran yang diterapkan oleh peneliti dapat meningkatkan hasil belajar siswa pokok bahasan gelombang MAN 1 Bandar Lampung secara signifikan.

Penelitian ini sejalan dengan apa hasil penelitian yang dilakukan Husni Sabil (2011) tentang Penerapan Pembelajaran Contextual Teaching \&
Learning (CTL) Pada Materi Ruang Dimensi Tiga menggunakan Model Pembelajaran Berdasarkan Masalah (MPBM) Mahasiswa Program Studi Pendidikan Matematika FKIP UNJA. Hasil penelitian menunjukkan terjadi peningkatan kualitas belajar mahasiswa dan hasil belajarnya. Secara numerik kesempurnaan kualitas perkuliahan mencapai $87,1 \%$, sedangkan rata-rata hasil belajar mahasiswa mencapai 77, Sehingga dapat disimpulkan bahwa pendekatan Contextual Teaching \& Learning (CTL) dengan Model Pembelajaran Berdasarkan Masalah (MPBM) dapat meningkatkan kualitas dan hasil belajar pada materi Ruang Dimensi Tiga Mahasiswa Program Studi Pendidikan Matematika.

Muhamad Fajar Buana (2012) tentang Penerapan CTL Dengan Kooperatif NHT Pada Mata Pelajaran Biologi. Hasil penelitian menunjukkan peningkatan Motivasi Belajar Klasikal Keseluruhan (MBKK) yaitu 43\% (siklus I) menjadi $86 \%$ (siklus II). Peningkatan MBKK juga diikuti peningkatan Motivasi Belajar Klasikal setiap Indikator Motivasi (MBKSI) meliputi minat 14\% (siklus I) menjadi $57 \%$ (siklus II), perhatian 57\% (siklus I) menjadi $86 \%$ (siklus II), konsentrasi $86 \%$ (siklus I) menjadi 100\% (siklus II) dan ketekunan $43 \%$ (siklus I) menjadi $100 \%$ (siklus II).

Hasil ketuntasan belajar yang peneliti lakukan tidak jauh berbeda dengan penelitian yang dilakukan oleh Setiawan, Didik (2012 Peningkatan hasil belajar siswa ditunjukkan dengan nilai rata-rata hasil belajar IPA tentang ciri - ciri khusus makhluk hidup pada setiap siklus. Pada pratindakan nilai rata-rata hasil evaluasi siswa adalah 53, pada siklus I meningkat 18,04 (dari 53 menjadi 71,04), dan pada siklus II meningkat 7,00 (dari 71,04 menjadi 78,04). Penelitian ini menyimpulkan bahwa penggunaan pendekatan CTL dinilai berhasil dan dapat meningkatkan hasil belajar IPA tentang ciri-ciri khusus makhluk hidup. 
Demikian juga penelitian oleh Permatasari, I., Jamzuri, J., \& Wahyuningsih, D. (2013). Hasil penelitian menunjukkan bahwa Mind Mapping Program melalui model pembelajaran Contextual Teaching Learning (CTL) dapat meningkatkan hasil belajar fisika siswa kelas XI.A2 SMA Negeri 4 Surakarta Tahun Ajaran 2012/2013 pada materi pokok fluida dinamis. Peningkatan hasil belajar fisika siswa berdasarkan aspek kognitif yakni ketuntasan belajar fisika oleh siswa pada siklus I sebesar $83,33 \%$ yang kemudian meningkat menjadi $90 \%$ pada siklus II dari target yang ditetapkan yakni ketuntasan belajar siswa sebesar $75 \%$.

\section{SIMPULAN}

Berdasarkan analisis dan pembahasan dapat diambil kesimpulan bahwa

1. Strategi Pembelajaran Melalui Pendekatan Kontekstual dengan Cooperative Learning dapat Meningkatkan Hasil Belajar Gelombang siswa Kelas XII.A.1 semester 1 MAN 1 Bandar Lampung pada setiap siklusnya.

2. Ketuntasan hasil belajar siswa meningkat pada siklus I dari 23,33 $\%$ menjadi $40 \%$ atau meningkat $71,43 \%$. Pada siklus II dari $40 \%$ menjadi $73,33 \%$ atau meningkat $83,33 \%$. Pada siklus III dari $73,33 \%$ menjadi $86,67 \%$ atau meningkat $18,18 \%$.

3. Nila Rata-rata hasil belajar siswa meningkat pada siklus I dari 62,80 menjadi 67,90 atau meningkat $8,12 \%$, pada siklus II dari 67,90 menjadi 75,70 atau meningkat $11,49 \%$, pada siklus III dari 75,70 menjadi 79,77 atau meningkat $5,37 \%$.

\section{DAFTAR PUSTAKA}

Arikunto, Suharsimi. 1992. Dasar-Dasar Evaluasi Pendidikan. Bumi Aksara. Jakarta.

Bahri Djarnarah Syaiful, 2002, Psikologi Belajar. PT Asdi Mahasatya, Jakarta

Depdikbud. 1994. Petunjuk Proses Belajar Mengajar. Departemen Pendidikan dan Kebudayaan. Jakarta.

Dimyati dan Mudliono,2006, Belajar dan Pembelajaran, PT Rineka Cipta, Jakarta

Hamalik Oumar, 1990, Metode Belajar dan Kesulitan-Kesuiilan Belajar, Tarsito Bandung.

Ibrahim, Muslimin dkk. 2000. Pembelajaran Kooperatif University Press. Universitas Surabaya. Surabaya.

Komalasari. (2010). Pembelajaran Kontekstual. PT Refika Aditama: Bandung

Muslich, Mansur. 2009. KTSP Pembelajaran Berbasis Kompetensi dan Kontekstual. Bumi Aksara Jakarta:

Sardirnan. Am. 2006. Interaksi dan rnotivasi belajar mengajar, Rajawali, Jakarta

Slameto, 1995, Belajar dan Faktor -faktor yang mempengaruhi, PT Rineka Cipta, Jakarta

Slavin, RE. 1995. Cooperative Learning. Teory, Research, and Practice. Boston Allyn and Bacon. USA.

Sanjaya, Wina. 2006. Strategi Pembelajaran berorientasi standar proses pendidikan. Kencana Prenada Media Group ,Jakarta.

Yulianti, D., Lestari, M., \& Yulianto, A. (2010). Penerapan Jigsaw Puzzle Competition dalam Pembelajaran Kontekstual untuk Meningkatkan Minat dan Hasil Belajar Fisika Siswa SMP. Jurnal Pendidikan Fisika Indonesia (Indonesian Journal of Physics Education), 6(2).84-89 Tersedia 
http://journal.unnes.ac.id/nju/index. php/JPFI/article/viewFile/1118/103 3

Sabil, H. (2011). Penerapan Pembelajaran Contextual Teaching \& Learning (CTL) Pada Materi Ruang Dimensi Tiga menggunakan Model Pembelajaran Berdasarkan Masalah (MPBM) Mahasiswa Program Studi Pendidikan Matematika FKIP UNJA. EDUMATICA Journal Pendidikan Matematika, 1(01). 4459. Tersedia di http://online journal.unja.ac.id/index.php/eduma ica/article/viewFile/185/167

Buana, Muhamad Fajar. 2012. Penerapan CTL dengan Kooperatif NHT pada mata pelajaran biologi un $\neg$ tuk meningkatkan motivasi belajar siswa sma muhammadiyah 1 malang. Prosiding Seminar Biologi. Vol. 9. No. 1. 353-359. Tersedia di http://jurnal.fkip.uns.ac.id/index.ph p/prosbio/article/view/1102
Setiawan, D. 2012, Upaya Meningkatkan Hasil Belajar Ipa Tentang Ciri-Ciri Khusus Makhluk Hidup Dengan Pendekatan Ctl (Contextual Teaching And Learning) Bagi Siswa Kelas VI Sdn Teges Purworejo (Doctoral Dissertation, Universitas Negeri Yogyakarta).

Permatasari, I., Jamzuri, J., \& Wahyuningsih, D. (2013). Penerapan media mind mapping programpada model pembelajaran contextual teaching and learning (CTL) untuk meningkatkan motivasi dan hasil belajar fisika pada siswa kelas XI. A2 SMA negeri 4 surakarta. Jurnal Pendidikan Fisika, 1(2). Teredia di http://www.jurnal.fkip.uns.ac.id/ind ex.php/pfisika/article/viewFile/2799 $/ 1915$ 